\title{
Evaluation of expansivity of Neogene clays and glacial tills from central Poland (Warszawa area) on the basis of suction tests
}

\author{
Dorota IZDEBSKA-MUCHA ${ }^{1}$ and Emilia WÓJCIK ${ }^{1, *}$ \\ 1 University of Warsaw, Institute of Hydrogeology and Engineering Geology, Faculty of Geology, Żwirki i Wigury 93, 02-089 \\ Warszawa, Poland
}

Izdebska-Mucha, D., Wójcik, E., 2015. Evaluation of expansivity of Neogene clays and glacial tills from central Poland (Warszawa area) on the basis of suction tests. Geological Quarterly, 59 (3): 593-602, doi: 10.7306/gq.1233

This paper presents the characteristics of the expansivity and quantitative prediction of heave of clay soils from Poland based on suction testing. Eleven Neogene clays and six glacial tills, differing in genesis and plasticity, were analysed to identify the expansive potential using eight empirical methods. The laboratory studies included measurements of soil-water characteristic curves and soil index properties. Data from water content, volume and suction measurements served to determine the suction compression index $C_{h}$ and the suction-water content index $\Delta h / \Delta w$ of the soils examined. The values of these indices are clearly dependent on the clay fraction content in tested soils. Compared with glacial tills, Neogene clays are expected to exhibit greater changes in volume due to changes in soil suction. Comparative results of the evaluation of expansivity suggest that the chosen classification methodologies provided consistent expansion ratings for glacial tills, while the values for Neogene clays vary from low to very high. The lowest expansivity classes have been obtained from evaluation based on soil suction. The McKeen (1992) method has been adopted for calculations of the potential field heave of Neogene clays and glacial tills. In order to provide a rational estimation of expansive soil behaviour, specialists should take into consideration the specific site and design features.

Key words: expansive soil, Neogene clays, glacial tills, suction, suction compression index, heave.

\section{INTRODUCTION}

Foundation engineering on expansive soils is regarded as one of the difficult geotechnical tasks. According to the standing rules and Polish legal regulations, the engineering conditions of expansive soil are defined as complex and building objects erected under complex soil conditions, are classified into the third geotechnical category (Rozporządzenie, 2012). Compared with other mineral soils, swelling clays are one of the most expensive geologic hazards. Practical recommendations and guidelines as to designing foundations, executing foundation works, as well as conservation and protection of existing objects were given by Przystański (1990). In the light of available investigations, one of the main causes of damages of buildings erected on expansive soils is improper founding systems and inadequate structural bracing (Jeż, 1989; Kumor, 1990, 1994, 2008). In geotechnical engineering practice, the range of soil investigations is usually limited to the main physical and mechanical (e.g., shear strength) parameters. As reported by professional literature, Neogene clays in Poland are most often stiff and firm, have a high shear strength and low

\footnotetext{
* Corresponding author, e-mail: wojcike@uw.edu.pl
}

Received: March 4, 2015; accepted: April 27, 2015; first published online: May 22, 2015. compressibility, thus providing favourable conditions for land development (Kumor, 2008). However, their sensitivity to moisture changes that determine a proper soil/building interaction during construction work, and predicted exploitation time are, as a rule, underestimated.

Numerous attempts have been made to systematise factors controlling the changes in the volume of clay soils. Noteworthy is that the deformation ability is distinctive of potential soil due to activation of the factor which initiates shrinkage or swelling of soils susceptible to such processes. Expansivity is controlled not only by the composition of soil described on the basis of conventional indices (grain-size distribution, clay fraction content, mineral composition of the clay fraction, type of the exchange cation, chemical composition of pore water), but is induced also by various factors in a soil environment sensitive to expansion. These environmental factors include: climatic changes (long-lasting draughts, torrential rains), human impact (spatial development densely built-up areas, root effect, use effects - extensive watering of lawns, poor insulation of heating systems, failure of water supply systems). Due to these factors, a near-surface zone, called the active zone, is formed. It covers the depth of the soil that interacts with the surface environmental conditions and is characterized by variable moisture content and suction (Fig. 1). Other crucial factors are: the state of stress, the structure/texture as well as initial moisture and saturation degree of the soil. Therefore, a rational approach to planning the investigations of such soils is recommended, with special emphasis on mineralogy, direct determinations of swelling and shrinkage parameters, and changes of strength due to volume changes. 


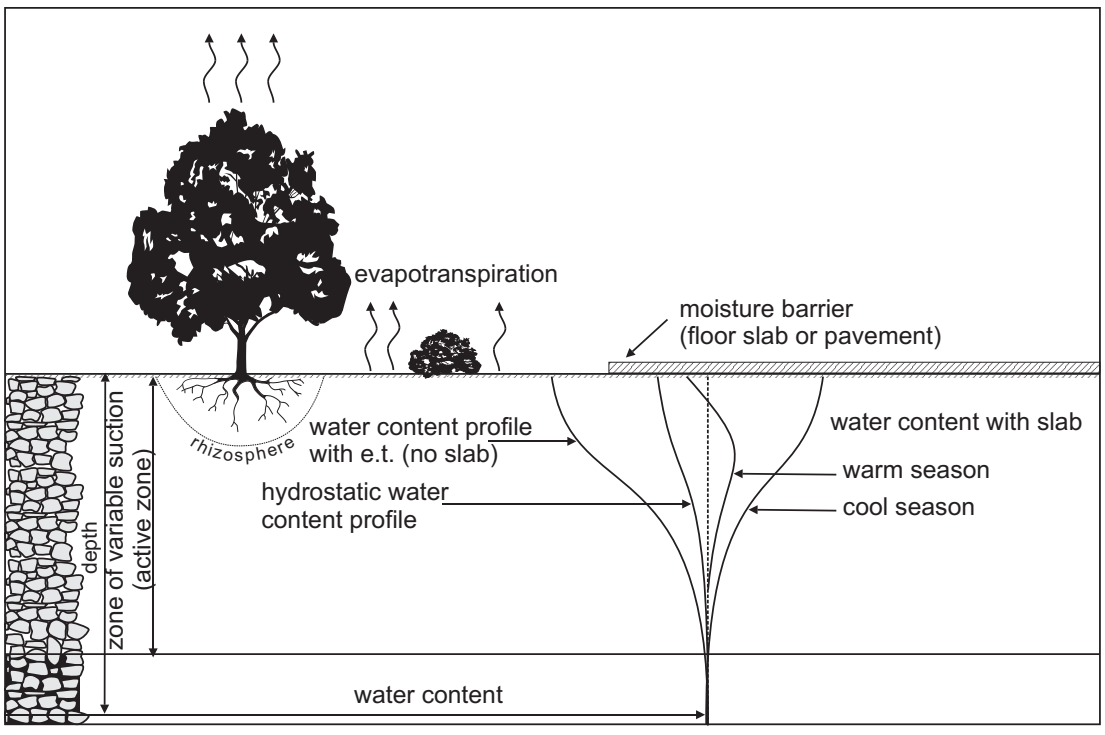

Fig. 1. Water content profiles in the active zone (Nelson and Miller, 1992; modified)

Expansive soils present significant geotechnical and engineering challenges all over the world. Therefore, the identification of soils sensitive to volumetric changes has been the subject of active research for the past 40 years. At the turn of the last decades, several tens of various classifications have been created (for comprehensive review see Izdebska-Mucha and Wójcik, 2014). Three types of approaches for estimating soil expansivity have been adopted. The first group includes methods based on empirical correlation of engineering index properties of soils e.g., liquid limit - LL, plasticity index - PI, clay content. The second approach defines expansivity in terms of swelling parameters determined in oedometer measurements. The third one employs total suction testing for the assessment of the degree of volume change. Johnson and Snethen (1978) have been the first to use the suction parameter in expansive soils classification. Initially, a definition and descriptions of practical use of soil suction appeared rarely in professional literature due to the lack of simple and reliable methods of suction determination. On the other hand, the role of moisture changes in soil was commonly underestimated. Conventional soil mechanics were focused on problems related to the full saturation state or completely dry formations. Numerous reports of expansive soil problems and resulting damages had been made available in various countries, which convinced the geotechnical engineering community to devote particular attention to soils existing between these two extreme stages. The parameter which most accurately describes the state of unsaturated/partly saturated soils is suction. Soil suction is a macroscopic property that indicates the intensity or energy level with which a soil sample attracts water. The soil-water characteristic curve (SWCC) is an important soil function relating the water content of a soil to soil suction, and it has become of great value in estimating functions of unsaturated soil properties (Fredlund, 1995). On the log scale, soil suction varies with water content in a wide range. This is an extremely sensitive parameter defining various soil properties (e.g., physical, chemical and mineralogical) essential in engineering practice. The shape and run of the soil-water characteristic curve is indicative of the suction-water content index $\Delta h / \Delta w$, suggested by McKeen (1992) for estimation of soil expansivity. Another method, based on soil suction in situ is the United States Army Engineer Waterways Experiment Station (USAEWES) classification system (Snethen et al., 1977), where consistence parameters are additionally taken into account.

Whilst much research has been carried out to characterize the mineralogy, index properties, swelling and expansivity of Polish clay soils (e.g., Niedzielski et al., 1988; Kaczyński and Grabowska-Olszewska, 1997; Gawriuczenkow, 2003, 2008), few data on soil suction have been published and are available in Polish databases (e.g., Garbulewski and Żakowicz, 1993a, b, 1995; Wojtasik, 1994, 1997; Barański and Wójcik, $2007,2008)$. In the light of the above, this paper is also intended to fill this gap and to present the characteristics of suction of Polish Neogene clays and glacial tills. The authors relate the results discussed herein to the previous findings, which permits a comprehensive evaluation of soil expansivity based on various methodological procedures.

Foundation design on expansive clay sites requires a reliable classification of soil expansivity and a quantitative assessment of probable volume changes. Thus, prior to foundation design, the soil heave should be known. The classification system by McKeen (1992) permits to predict the heave and soil expansivity. However, it is widely acknowledged that no universal classification system for all soils exists, but the correlations may vary within climatic and geological zones. More reliable results can be obtained locally for given subsoil and site conditions. Another purpose of this paper is to adopt McKeen's (1992) methodology to estimate the behaviour of potentially expansive soils from Poland, based on assumptions applicable to local conditions and actual measurements of the considered soils.

Soils described in this paper are partly the same ones that have been examined in the previous study (Neogene clays from the Dobre polygon) and the collected experimental data come from a number of research projects conducted in the Department of Engineering Geology, Faculty of Geology, University of Warsaw, over the past several years. The selection of material was determined by the fact that for these samples additional measurements of the soil-water characteristic curve were carried out by the present authors.

\section{MATERIALS AND METHODS}

The cohesive soils selected for this research are common subsoils for numerous objects in more than a half of the area of Poland. The distribution of sampling sites is given in Figure 2. Polygons 1-3 are represented by Neogene clays. The former two are located in the Stegny and Buraków districts of Warszawa, respectively (samples: C-W1-C-W4 and C-WB5, CWB6), and polygon 3 in the locality of Dobre (samples: C-D1-C-D5) about $50 \mathrm{~km}$ north-east of Warszawa. Polygons 4-6, located in Warszawa (districts of Ochota and Służew), are represented by glacial tills of the Odra and Warta glaciations (samples: T1-T6).

In total, 17 samples have been classified in accordance with the Unified Soil Classification System (USCS, according to ASTM D 2487-06) mainly as CH fat clays and SC clayey sand, for which the basic physical parameters such as clay content $(\mathrm{Cl})$ and Atterberg limits (LL, PL) have been defined. The results are given in Table 1. 


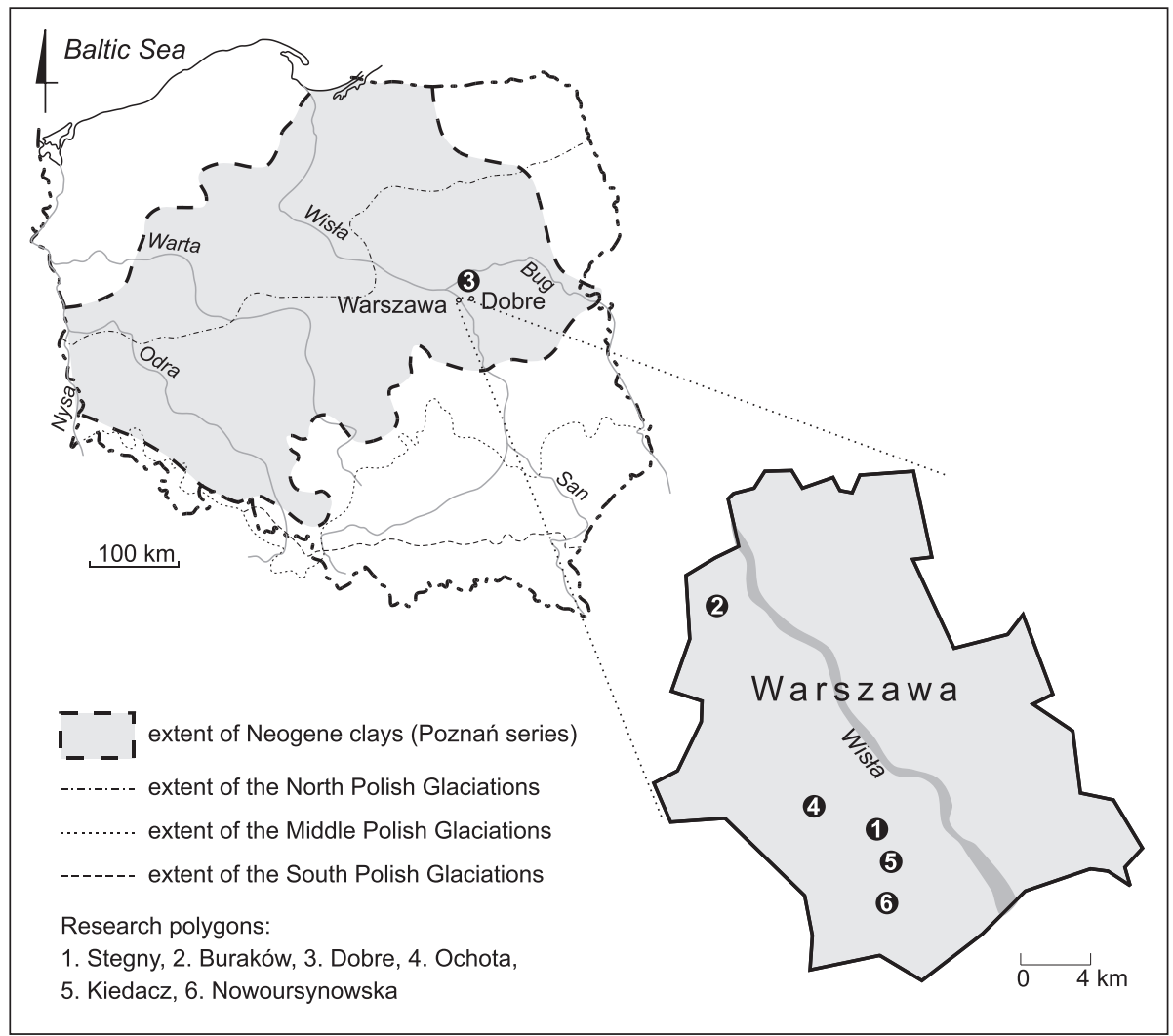

Fig. 2. Location map of the study area showing distribution of various soil types and sampling sites

Summary of properties of tested soil samples

\begin{tabular}{|c|c|c|c|c|c|c|}
\hline \multicolumn{2}{|c|}{ Soil type } & Sample ID & $\begin{array}{c}\text { Soil classification } \\
\text { USCS }\end{array}$ & $\begin{array}{c}\text { Clay content } \\
\mathrm{Cl}[\%]\end{array}$ & $\begin{array}{l}\text { Liquid limit } \\
\text { LL [\%] }\end{array}$ & $\begin{array}{l}\text { Plastic limit } \\
\text { PL [\%] }\end{array}$ \\
\hline \multirow{11}{*}{\multicolumn{2}{|c|}{ Neogene clays }} & C-W1 & $\mathrm{CH}$ fat clay & 80 & 96.0 & 41.0 \\
\hline & & C-W2 & $\mathrm{CH}$ fat clay & 72 & 83.0 & 35.0 \\
\hline & & C-W3 & $\mathrm{CH}$ fat clay & 63 & 69.5 & 22.5 \\
\hline & & C-W4 & $\mathrm{CH}$ fat clay & 70 & 70.1 & 31.1 \\
\hline & & C-WB5 & $\mathrm{CH}$ fat clay & 65 & 99.0 & 32.3 \\
\hline & & C-WB6 & $\mathrm{CH}$ fat clay & 61 & 64.4 & 25.4 \\
\hline & & C-D1 & $\mathrm{CH}$ fat clay & 88 & 71.1 & 30.9 \\
\hline & & C-D2 & $\mathrm{CH}$ fat clay & 60 & 69.6 & 23.7 \\
\hline & & C-D3 & $\mathrm{CH}$ fat clay & 72 & 82.5 & 31.7 \\
\hline & & C-D4 & $\mathrm{CH}$ fat clay & 58 & 76.9 & 27.4 \\
\hline & & C-D5 & $\mathrm{CH}$ fat clay & 85 & 111.9 & 38.5 \\
\hline \multirow{6}{*}{ Glacial tills } & \multirow{4}{*}{ Warta Glaciation } & $\mathrm{T}-1$ & CL sandy lean clay & 21 & 20.6 & 12.0 \\
\hline & & T-2 & SC-SM silty clayey sand & 18 & 19.3 & 13.7 \\
\hline & & T-3 & SC clayey sand & 12 & 23.0 & 12.5 \\
\hline & & T-4 & SC-SM silty clayey sand & 10 & 19.1 & 12.4 \\
\hline & \multirow{2}{*}{ Odra Glaciation } & T-5 & SC clayey sand & 20 & 22.3 & 11.1 \\
\hline & & $\mathrm{T}-6$ & SC clayey sand & 15 & 24.4 & 11.4 \\
\hline
\end{tabular}

The relationship between soil moisture and suction has been examined using the pressure plate apparatus (Soilmoisture Equipment Corp. model 1500). The main elements of this apparatus are a pressure chamber, a porous ceramic plate and a compressor producing pressure. This method permits to complete a number of determinations of soil moisture content at different pressures. In the laboratory, the samples were placed in small cylinders (about $54 \mathrm{~mm}$ in diameter and $20 \mathrm{~mm}$ in height), saturated and subsequently balanced with respect to the increasing values of the suction. The moisture tensions were obtained by creating a series of under- and over-pressures. Weighing of the sample after each balance adjustment yields the moisture content for each suction tension. Each determination has been completed on at least three identical samples and the results used in further investigations are their arithmetic mean. Thus, the obtained curve, illustrating the depend- 
ence between the pressure and the moisture, is a typical desorption (drying) curve. Samples from the Stegny and Ochota polygons show pressure values exceeding pF 4.2 (measurements completed using a psychrometer), which enabled a thorough description of soil behaviour within a wider suction pressure range. A single determination procedure lasted from 7 to 15 days. It has been assumed that the balance between pressure inside the chamber, soil and pressure plate is attained when water ceases to flow out of the chamber. When each of the applied suction was equalized, the height, diameter and mass of each specimen were measured. The relationship between soil suction and water content (SWCC) was determined for 17 different soil samples - 6 glacial clays, and 11 Neogene clays. Figure 3A shows data illustrative for each type of soil. This relationship allows determining the suction-water content index $\Delta h / \Delta w$, defined as the slope between the suction levels of 6 and $3 \mathrm{pF}$. Using pairs of volume measurements - at the imposed suction level and after drying the samples at $105^{\circ} \mathrm{C}-\mathrm{a}$ change of volume can be computed according to the equation:

$$
\Delta V=\frac{V_{i}-V_{d}}{V_{i}}
$$

where: $\Delta V$-volume change, $V_{i}-$ volume of the sample at the given suction level $\left[\mathrm{cm}^{3}\right], V_{d}$ - final volume of the sample after drying at $105^{\circ} \mathrm{C}\left(378^{\circ} \mathrm{K}\right)\left[\mathrm{cm}^{3}\right]$

In Figure $3 \mathrm{~B}$, volume change $(\Delta V)$ measurements are plotted versus the corresponding suction $(h)$ level. This relationship permits to calculate the suction compression index $C_{h}$, which is the slope of the volume change-suction relation in the suction range of $2.0-2.5 \mathrm{pF}$ to $5.5 \mathrm{pF}$, and represents soil response to the suction change. The values of $C_{h}$ identified for selected examples of Neogene clays and tills are -0.1209 and -0.0192 , respectively, which is reflected in the differences in the slopes tills have clearly flattened slopes and less negative values of $C_{h}$ than clays.

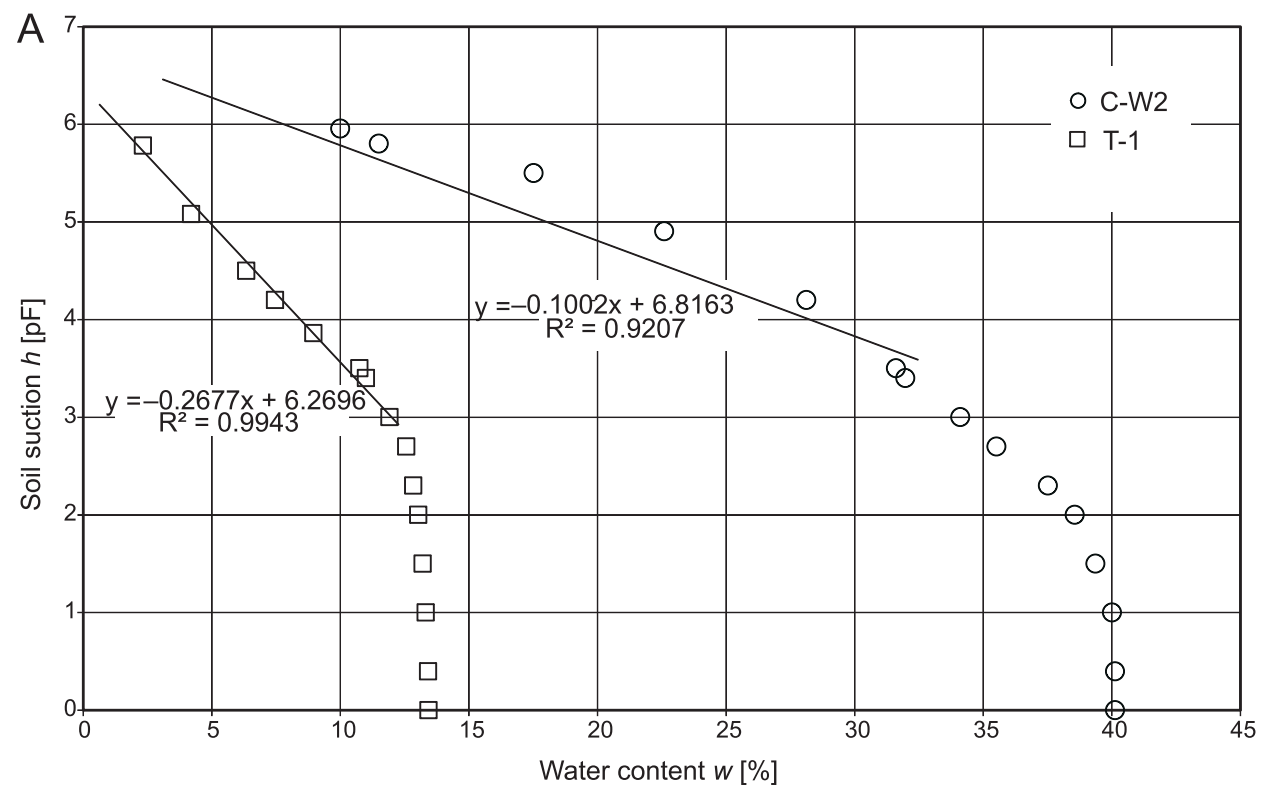

B

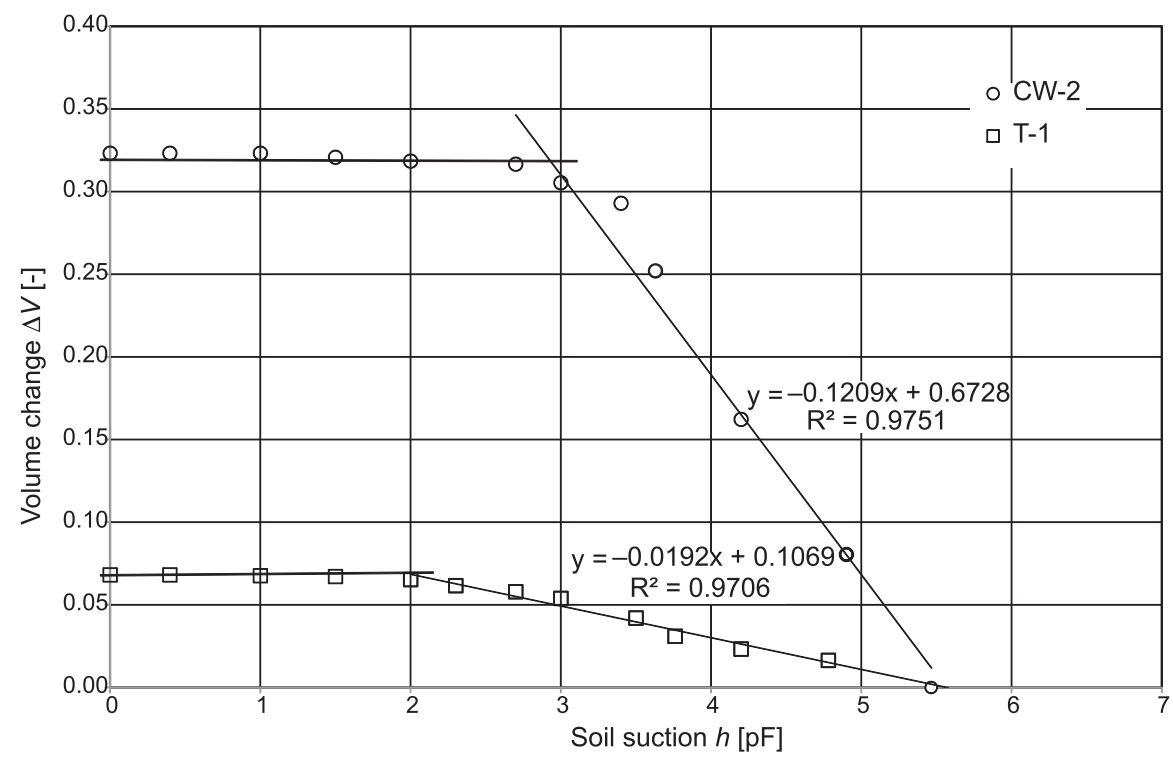

Fig. 3. Examples of A - soil-water characteristics curves, B - volume change-suction relation of Neogene clays (CW-2) and glacial tills (T-1) 
McKeen (1992) has proposed an expansive soil classification methodology based on soil suction testing, which yields:

- a qualitative assessment of soil expansivity categorising the soils into five classes: nonexpansive, low, moderate, high and special case (very high);

- a quantitative prediction of heave corresponding to these categories, computed for given site and design conditions (Table 2).

The classification system is based on two relationships: 1) soil suction versus water content and 2) volume change versus soil suction (Fig. 3). On the basis of these two indices the expansive soils were classified and the heave of the considered soil layer may be calculated from equation:

$$
\Delta H=C_{h} \cdot \Delta h \cdot \Delta t \cdot f \cdot s
$$

where: $\Delta H$ - heave (the vertical movement of the soil layer), $C_{h}-$ suction compression index, $\Delta h$-suction change in the soil layer, $\Delta t$ - thickness of the soil layer, $f$ - lateral restraint factor $f=\left(1+2 K_{0}\right) / 3$; $K_{0}$ - coefficient of earth pressure at rest, $s$ - coefficient of load effect on heave, $s=1-[0.01 \cdot(\% S P)]$, for $\% S P \leq 50, \%$ SP being the percentage of swell pressure (SP) applied

The proposed methodology was adopted to predict the potential heave of Neogene clays and glacial tills from Poland with respect to the local soil and climatic characteristics. Therefore, the heave was computed using the following data and assumptions:

- $C_{h}$ - average values were assumed from the measurements of the tested soil samples, Neogene clays: $C_{h}=$ $-0.101 \pm 0.028$; glacial tills: $C_{h}=-0.018 \pm 0.005$.

- $\Delta h$ - to take account of the most unfavourable conditions in the ground, the average of the maximum range of the suction change that can occur in the field (from 6 to $2 \mathrm{pF}$ ) was assumed: $\Delta h=(6-2) / 2=2 \mathrm{pF}$.

- $\Delta t$ - thickness of the soil layer, corresponding to the depth to which moisture changes occur in the ground (active zone). In professional literature, various data are reported for clays, depending on climatic and environmental factors, as for example: Fityus et al. (2004) about $2 \mathrm{~m}$, Jones and Jefferson (2012) - about $3 \mathrm{~m}$, Biddle (2001) - 1.5-2.0 m and McKeen (1992) - $1.5 \mathrm{~m}$. For the purpose of this research, the depth of $\Delta t=1.5 \mathrm{~m}$ was assumed for the active zone in Neogene clays. In Poland this depth covers the zone of significant moisture-volume changes. However, according to Jeż (1995), in clay soils it might be extended up to $3.5 \mathrm{~m}$ due

Table 2

Expansive soil classification system (McKeen, 1992)

\begin{tabular}{|l|c|c|c|c|c|}
\hline Category & $C_{h}$ & $\Delta h / \Delta W$ & $\begin{array}{c}\Delta H^{*} \\
{[\mathrm{~m}]}\end{array}$ & $\begin{array}{c}\Delta H \\
{[\%]}\end{array}$ & Remarks \\
\hline I & -0.227 & $>-6$ & 15.3 & 10.0 & special case \\
\hline II & $\begin{array}{c}-0.227 \\
-0.120\end{array}$ & $\begin{array}{c}-6 \text { to } \\
-10\end{array}$ & 8.1 & 5.3 & high \\
\hline III & $\begin{array}{r}-0.120 \\
-0.040\end{array}$ & $\begin{array}{c}-10 \text { to } \\
-13\end{array}$ & 2.7 & 1.8 & moderate \\
\hline IV & $\begin{array}{r}-0.040 \\
\text { nonexp. }\end{array}$ & $\begin{array}{c}-13 \text { to } \\
-20\end{array}$ & - & - & low \\
\hline V & nonexp. & $<-20$ & - & - & nonexp. \\
\hline
\end{tabular}

* $-\Delta H$ calculated for $f=0.5, Z_{a}=1.5 \mathrm{~m}(5 \mathrm{ft}), \Delta h=1.0 \mathrm{pF}, s=0.9$ to water transpiration by tree roots. For glacial tills the accepted thickness of the active zone is $\Delta t=0.6 \mathrm{~m}$ (after Pisarczyk, 2001).

- $K_{0}, f-$ four values of the coefficient of earth pressure at rest have been assumed to reflect various conditions in the ground; $K_{0}=0.5 ; 1 ; 2 ; 2.5$, which gives $f=0.67 ; 1.00$; $1.67 ; 2.00$ respectively.

- $s$ - three values of the coefficient for load effect on heave have been assumed: $s=0.5 ; 0.7 ; 0.9$, which illustrate the heave under loads corresponding to $50 \%$ SP, $30 \%$ SP and $10 \%$ SP, respectively.

By selecting adequate climate-induced variables and using data directly obtained in laboratory measurements, the estimation of potential heave is most likely to adequately reflect the local conditions.

\section{RESULTS AND DISCUSSION}

Figures 4 and 5 illustrate the effect of clay content on the suction-water content index and suction compression index. In Figure 4, suction-water content index $\Delta h / \Delta w$ values are plotted against clay percentage. It is thus evident that soils with a lower clay content tend to have a lower suction-water content index. Samples T1-6 with the clay content as low as about $20 \%$ have the most negative values of this index (from -30.68 to -24.72 ). For Neogene clays - with the clay content exceeding 60\% - the suction-water content index ranges from -15.43 to -8.65 . The relationship between the suction compression index $C_{h}$ and clay percentage (Fig. 5) shows a similar distribution of values samples T1-6 are clearly separated from the samples of Neogene clays. With the increase of clay content, the suction compression index $C_{h}$ values decrease, which indicates that soils become more sensitive to the change in water content and volume with respect to suction.

Figure 6 shows plots of the suction-water content index versus suction compression index $C_{h}$. The relationship obtained by the present authors has the form of $C_{h}=$ $\left[-0.0053^{*}(\Delta h / \Delta w)\right]-0.1628$ at $R^{2}=0.8456$ and generally agrees with the relationship reported by McKeen (1992). Tills have more negative $\Delta h / \Delta w$ values while the suction compression in$\operatorname{dex} C_{h}$ approaching zero. Such soils show insignificant changes of volume related to suction changes. Clays, in turn, exhibit lower (more negative) values of $C_{h}$ as $\Delta h / \Delta w$ approaches 0. Such soils are expected to exhibit considerable changes in volume due to changes in soil suction.

Table 3 shows the comparative results of expansivity obtained for glacial tills and Neogene clays using different methods. Results according to classification systems by Seed et al. (1962), van der Merwe (1964), IS 1498 (1970), Chen (1975), Yilmaz (2006), Yukselen and Kaya (2008) are presented along with the systems based on suction parameters: USAEWES (Snethen et al., 1977) and McKeen (1992). Such an approach adds considerably to the characteristics of the soils examined and provides a more comprehensive evaluation of soil expansivity. Results from Table 3 have revealed that the considered classification methodologies provide consistent expansion ratings for glacial tills and conflicting ones for samples of Neogene clays. Classifications by van der Merwe (1964), IS 1498 (1970) and Chen (1975) based on Atterberg limits and related parameters, assign a very high degree of expansivity, whereas the Seed et al. (1962), Yilmaz (2006) and Yukselen and Kaya (2008), systems, which consider soil mineralogy indicators, predict a high and a very high degree of expansivity. This confirms the findings of the present authors from their previous studies 


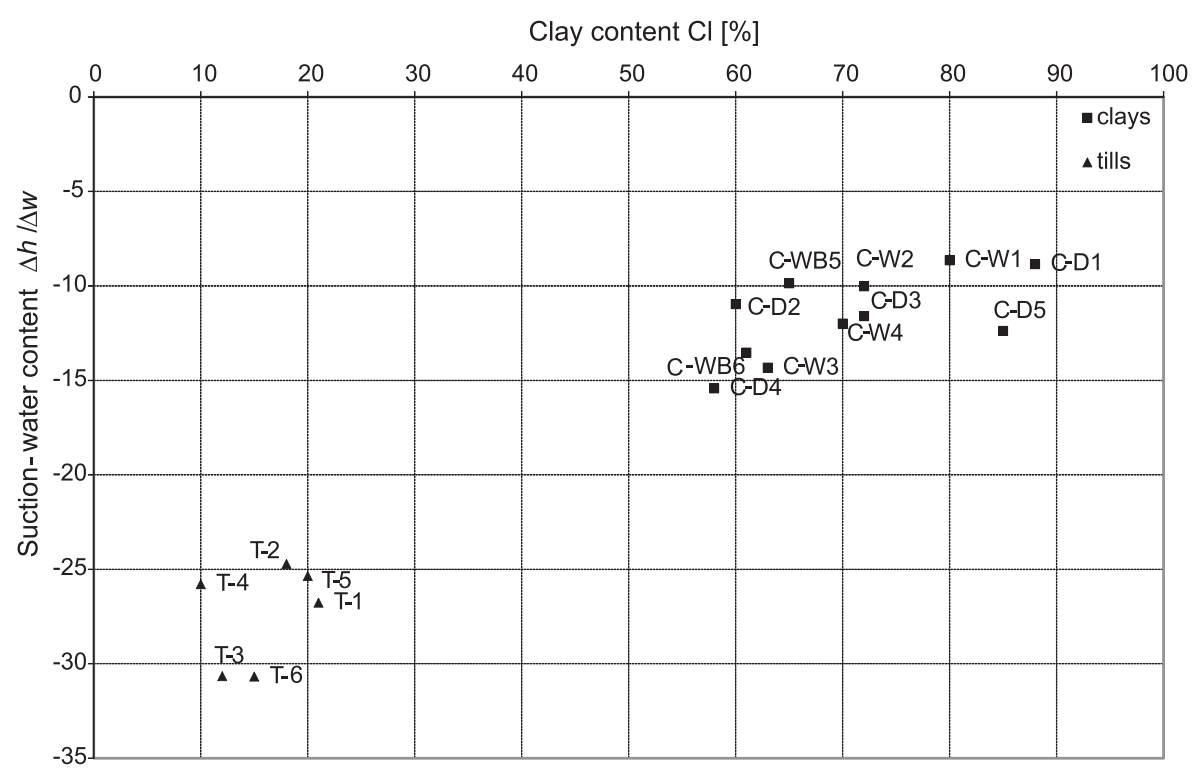

Fig. 4. Suction-water content index versus clay content

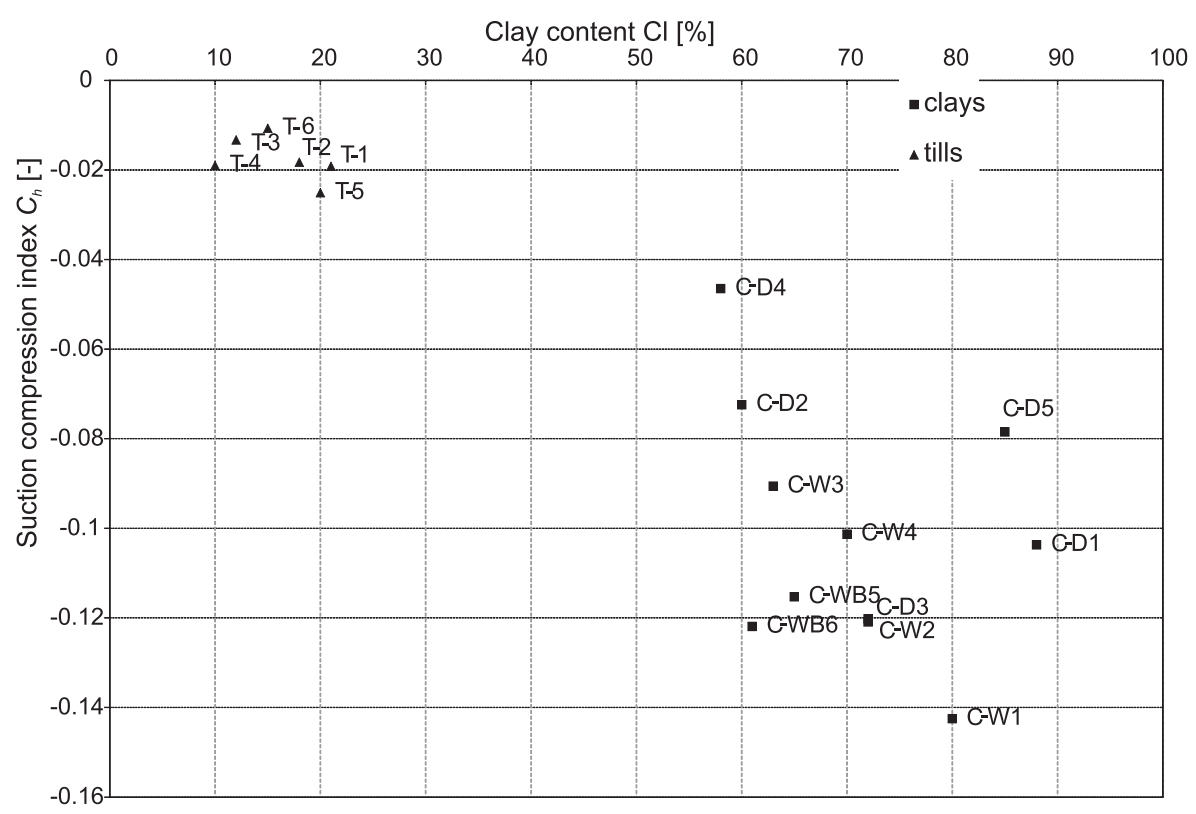

Fig. 5. Suction compression index versus clay content

(Izdebska-Mucha and Wójcik, 2014). According to the USAEWES (Snethen et al., 1977) classification, Neogene clays were identified as showing a high degree of expansion while high to low values have been revealed by the McKeen (1992) system. Similar results are reported by Sawangsuriya et al. (2011), who, applying different classification systems, confirmed that the lowest expansivity classes were obtained from the McKeen system (1992).

Figure 7 illustrates the evaluation of the potential expansivity of soils based on in situ moisture content and soil suction measurements (filter paper technique according to ASTM D 5298-94, filter paper Whatman no. 42) plotted on the classification system proposed by McKeen (1992). The results corroborate the conclusions from Table 3 and show that tills should be classified into category $\mathrm{V}$ - nonexpansive soils, while the expansivity of Neogene clays varies from high to low. Depend- ing on their expansivity class, the considered clays should be given due attention. For example, in case of highly expansive soils, the effects of volume change can be mitigated by very careful assessment of environmental factors. For the low degree of expansivity, a behaviour typical of expansive soils is not expected, therefore special consideration of shrink/swell behaviour is not required.

Figure 8 presents the calculations of the potential field heave of Neogene clays and glacial tills. For each soil, 12 variants have been computed with regard to different values of the load effect on heave $(s)$ and the coefficient of earth pressure at rest $\left(K_{0}\right)$. It has been found that the amount of potential heave increases with the increase of the coefficient of earth pressure at rest $\left(K_{0}=0.5 \rightarrow K_{0}=2.5\right)$ and the decrease of the applied load $(s=0.5 \rightarrow s=0.9)$. For the assumed variables, the heave of Neogene clays may vary within a wide range from 10 to 
Prediction of potential expansivity of Neogene clays and glacial tills by various classification systems

\begin{tabular}{|c|c|c|c|c|c|c|c|c|c|c|c|c|c|c|}
\hline \multirow[b]{2}{*}{$\begin{array}{l}\text { Soil } \\
\text { No. }\end{array}$} & \multirow[b]{2}{*}{$\begin{array}{l}\stackrel{0}{2} \\
\stackrel{2}{D} \\
\overline{\overline{\bar{c}}} \\
\dot{\infty}\end{array}$} & \multirow[b]{2}{*}{ 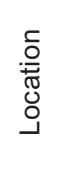 } & \multirow[b]{2}{*}{$\underset{\text { ID }}{\text { Sample }}$} & \multicolumn{3}{|c|}{ Soil parameters } & \multicolumn{8}{|c|}{ Classifications } \\
\hline & & & & $\begin{array}{l}\text { Clay } \\
\text { content } \\
\mathrm{Cl}[\%]\end{array}$ & $\begin{array}{c}\text { Liquid } \\
\text { limit } \\
\text { LL } \\
{[\%]}\end{array}$ & $\begin{array}{l}\text { Plasticity } \\
\text { index } \\
\text { PI [\%] }\end{array}$ & $\begin{array}{l}\text { Chen } \\
(1975)\end{array}$ & $\begin{array}{c}\text { IS } \\
1498 \\
(1970)\end{array}$ & $\begin{array}{l}\text { van der } \\
\text { Merwe } \\
(1964)\end{array}$ & $\begin{array}{l}\text { Seed at al. } \\
\quad(1962)\end{array}$ & $\begin{array}{c}\text { Yukselen } \\
\text { and Kaya } \\
(2008)\end{array}$ & $\begin{array}{l}\text { Yilmaz } \\
(2006)\end{array}$ & $\begin{array}{c}\text { USAEWES } \\
(1977)\end{array}$ & $\begin{array}{c}\text { McKeen } \\
\text { (1992) }\end{array}$ \\
\hline 1 & \multirow{11}{*}{ 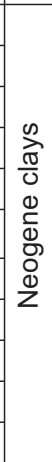 } & \multirow{6}{*}{$\begin{array}{l}\sum_{\pi}^{0} \\
N \\
N \\
\frac{N}{N} \\
3 \\
3\end{array}$} & C-W1 & 80.0 & 96.0 & 55.0 & $\mathrm{VH}$ & $\mathrm{VH}$ & $\mathrm{VH}$ & $\mathrm{VH}$ & $\mathrm{VH}$ & $\mathrm{VH}$ & $\mathrm{H}$ & $\mathrm{H}$ \\
\hline 2 & & & C-W2 & 72.0 & 83.0 & 48.0 & $\mathrm{VH}$ & $\mathrm{VH}$ & $\mathrm{VH}$ & $\mathrm{VH}$ & $\mathrm{VH}$ & $\mathrm{VH}$ & $\mathrm{H}$ & $\mathrm{H}$ \\
\hline 3 & & & C-W3 & 63.0 & 69.5 & 47.0 & $\mathrm{VH}$ & $\mathrm{VH}$ & $\mathrm{VH}$ & $\mathrm{VH}$ & $\mathrm{H}$ & $\mathrm{H}$ & $\mathrm{H}$ & $\mathrm{L}$ \\
\hline 4 & & & C-W4 & 70.0 & 70.1 & 39.0 & $\mathrm{VH}$ & $\mathrm{VH}$ & $\mathrm{VH}$ & $\mathrm{VH}$ & $\mathrm{H}$ & $\mathrm{H}$ & $\mathrm{H}$ & $\mathrm{M}$ \\
\hline 5 & & & C-WB5 & 65.0 & 99.0 & 66.7 & $\mathrm{VH}$ & $\mathrm{VH}$ & $\mathrm{VH}$ & $\mathrm{VH}$ & $\mathrm{VH}$ & $\mathrm{VH}$ & $\mathrm{H}$ & $M$ \\
\hline 6 & & & C-WB6 & 61.0 & 64.4 & 39.0 & $\mathrm{VH}$ & $\mathrm{VH}$ & $\mathrm{VH}$ & $\mathrm{H}$ & $\mathrm{H}$ & $\mathrm{H}$ & $\mathrm{H}$ & $\mathrm{L}$ \\
\hline 7 & & \multirow{5}{*}{ 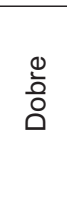 } & C-D1 & 88.0 & 71.1 & 40.2 & $\mathrm{VH}$ & $\mathrm{VH}$ & $\mathrm{L}$ & $\mathrm{H}$ & $\mathrm{H}$ & $\mathrm{H}$ & $\mathrm{H}$ & $\mathrm{M}$ \\
\hline 8 & & & C-D2 & 60.0 & 69.6 & 45.9 & $\mathrm{VH}$ & $\mathrm{VH}$ & $\mathrm{VH}$ & $\mathrm{VH}$ & $\mathrm{H}$ & $\mathrm{H}$ & $\mathrm{H}$ & $\mathrm{M}$ \\
\hline 9 & & & C-D3 & 72.0 & 82.5 & 50.8 & $\mathrm{VH}$ & $\mathrm{VH}$ & $\mathrm{VH}$ & $\mathrm{VH}$ & $\mathrm{H}$ & $\mathrm{VH}$ & $\mathrm{H}$ & $\mathrm{M}$ \\
\hline 10 & & & C-D4 & 58.0 & 76.9 & 49.5 & $\mathrm{VH}$ & $\mathrm{VH}$ & $\mathrm{VH}$ & $\mathrm{VH}$ & $\mathrm{H}$ & $\mathrm{H}$ & $\mathrm{H}$ & $\mathrm{L}$ \\
\hline 11 & & & C-D5 & 85.0 & 111.9 & 73.4 & $\mathrm{VH}$ & $\mathrm{VH}$ & $\mathrm{VH}$ & $\mathrm{VH}$ & $\mathrm{H}$ & $\mathrm{VH}$ & $\mathrm{H}$ & $M$ \\
\hline 12 & \multirow{6}{*}{ 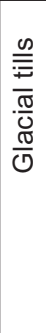 } & \multirow{4}{*}{$\begin{array}{l}\frac{\sigma}{\frac{\pi}{0}} \\
\frac{0}{\pi} \cdot \frac{\pi}{0} \\
3 \frac{\pi}{0}\end{array}$} & T1 & 21.0 & 20.6 & 8.6 & $\mathrm{~L}$ & $\mathrm{~L}$ & $\mathrm{~L}$ & $\mathrm{~L}$ & $\mathrm{~L}$ & $\mathrm{~L}$ & $\mathrm{~L}$ & $\mathrm{~N}$ \\
\hline 13 & & & $\mathrm{~T} 2$ & 18.0 & 19.3 & 5.6 & $\mathrm{~L}$ & $\mathrm{~L}$ & $L$ & $\mathrm{~L}$ & $\mathrm{~L}$ & $\mathrm{~L}$ & $\mathrm{~L}$ & $\mathrm{~N}$ \\
\hline 14 & & & T3 & 12.0 & 23.0 & 10.5 & $L$ & $L$ & $L$ & $L$ & $\mathrm{~L}$ & $L$ & $\mathrm{~L}$ & $\mathrm{~N}$ \\
\hline 15 & & & T4 & 10.0 & 19.1 & 6.7 & $\mathrm{~L}$ & $\mathrm{~L}$ & $\mathrm{~L}$ & $\mathrm{~L}$ & $\mathrm{~L}$ & $\mathrm{~L}$ & L & $\mathrm{N}$ \\
\hline 16 & & \multirow{2}{*}{$\begin{array}{l}\frac{\sigma}{\frac{0}{0}} \\
\frac{0}{0} \cdot \frac{\pi}{0} \\
\frac{\pi}{0}\end{array}$} & T5 & 20.0 & 22.3 & 11.2 & $\mathrm{~L}$ & $\mathrm{~L}$ & $\mathrm{~L}$ & $\mathrm{~L}$ & $\mathrm{~L}$ & $\mathrm{~L}$ & $\mathrm{~L}$ & $\mathrm{~N}$ \\
\hline 17 & & & T6 & 15.0 & 24.4 & 13.0 & $\mathrm{~L}$ & L & L & $\mathrm{L}$ & L & L & L & $N$ \\
\hline
\end{tabular}

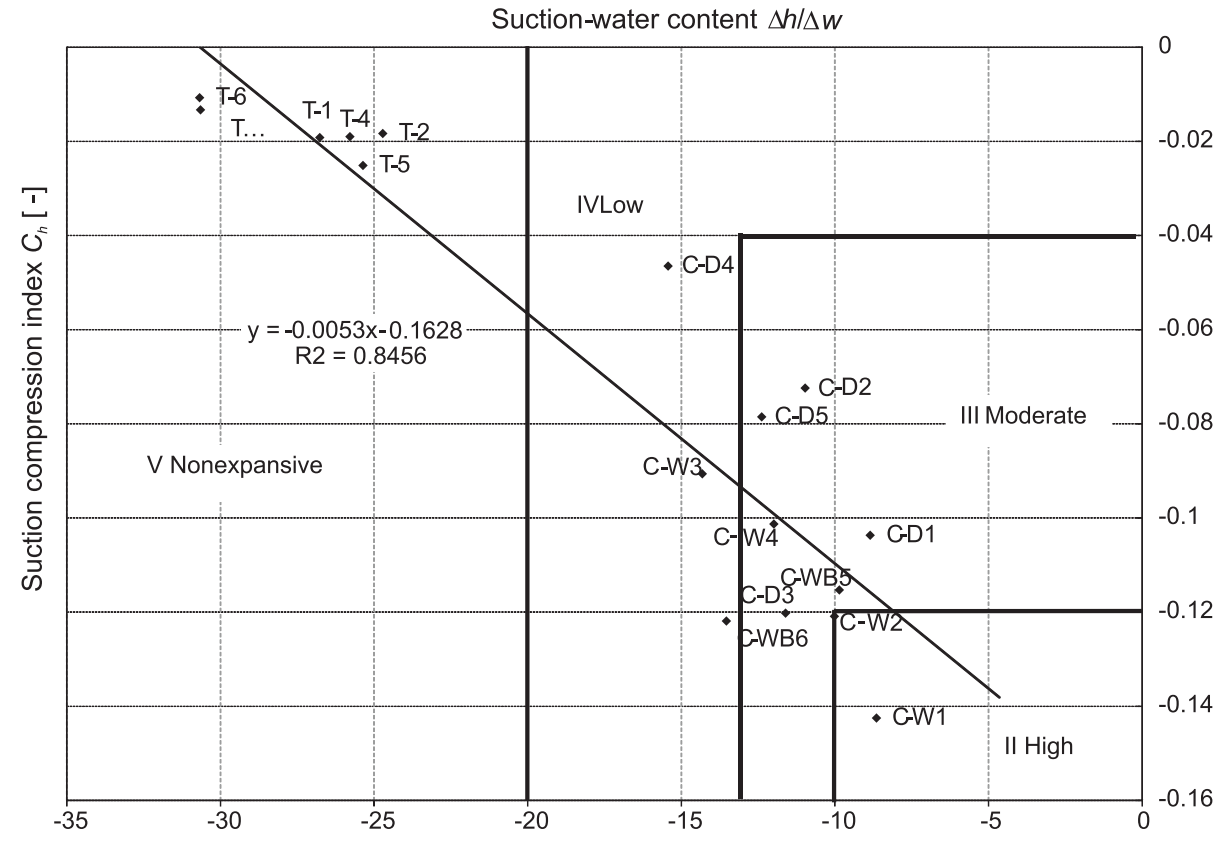

Fig. 6. Suction compression index $\left(C_{h}\right)$ versus suction-water content index $(\Delta h / \Delta W)$ with McKeen (1992) classification of expansive soils

$55 \mathrm{~cm}$, whereas for glacial tills the values change between 0.7 to $3.8 \mathrm{~cm}$. These estimates indicate that a serious vertical movement may occur at the top $1.5 \mathrm{~m}$ of clays in response to an average suction change of $2 \mathrm{pF}$. For glacial tills, the results agree well with the aforementioned classifications and indicate their very low sensibility to suction changes in terms of their potential to volume change.
In order to provide a rational estimation of the studied soils behaviour based on the findings presented in Figure 8, specialists should take into consideration the specific site and design features. One of the important factors in estimation of heave is the coefficient of earth pressure at rest - a parameter strictly related to stress conditions in a soil. According to Szczepański (2007), soil preconsolidation is a total effect of mechanical preconsolidation (glacier pressure, overburden pressure, water 


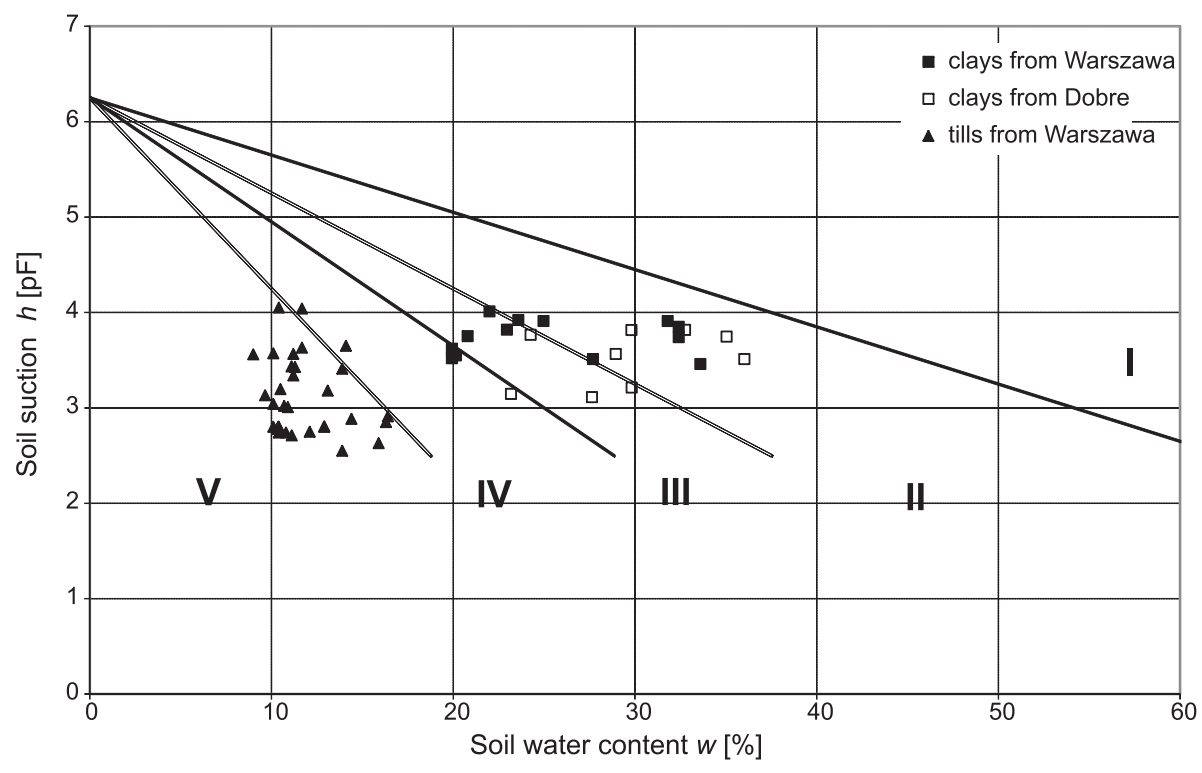

Fig. 7. Potential expansivity of Neogene clays and glacial tills on the McKeen (1992) classification chart

I - special case, II - high, III - moderate, IV - low, V - nonexpansive

table fluctuations) as well as apparent preconsolidation (ageing effect, structural strengthening) resulting from processes such as cementation, recrystallisation of minerals, changes of pore water chemistry and others. Both soils considered in this study are overconsolidated due to glaciations history, which points to $K_{0}$ $>1$. Data reported by Barański et al. (2004) indicate that the average value of $K_{0}$ of Neogene clays from Warszawa is 1.1, as determined by several field methods. Recent field monitoring of $K_{0}$ in the polygon Warszawa Stegny yielded values of $K_{0}=1.5$ (Barański, pers. comm., 2014). In the case of the glacial tills occurring in the edge zone of the glacial till plain (polygons 5 and 6), the ageing processes might be of particular importance. According to Kaczyński et al. (2010), who studied the geological engineering properties of glacial tills of the Warta and Odra glaciations from the area of Warszawa, compared to typical glacial tills from other sites in Warszawa, the tills from the Służew area exhibit a higher consolidation manifested by low values of porosity, moisture content and degree of saturation and a high consistency index. In situ cone penetrometer testing (CPT) revealed the average value of $K_{0}$ for tills to be $K_{0}=2.4$ (Kaczyński et al., 2008). Another important factor in heave estimation is the applied load, which restrains the soil swelling. This effect is expressed in terms of a percentage of swell pressure removed, and represented by the coefficient $s$ in heave computations. As reported by Barański and Wójcik (2007), the average swelling pressure of the tested clays was $200 \mathrm{kPa}$. Therefore, the assumed $s$ values $=0.5 ; 0.7 ; 0.9$ correspond to the applied loads of 100,60 and $20 \mathrm{kPa}$, respectively. The swelling pressure of the tested tills is very low and does not exceed $15 \mathrm{kPa}$ (Kaczyński et al., 2010), which points to the lowest values of $s$ as the most rational in heave estimation of this type of soil.

\section{SUMMARY}

Expansive soils are those which exhibit significant volume changes due to changes in water content. Various classification systems have been developed over the past decades to evalu- ate soil expansivity. With this respect, suction is considered to be a more definitive and reliable measure of potential expansion than the index soil properties. This paper discusses:

- the characteristics of suction of Neogene clays and glacial tills from six different locations in central Poland;

- the comparison of expansivity of the soils based on suction and index properties of soil;

- the estimate of heave calculated according to the method of McKeen (1992). This method was adopted to reflect Polish conditions by using the assumptions that correspond to local environmental, site and design conditions along with the actual suction-volume change measurements of the studied soils.

A thorough analysis of the effect of the clay content on the suction-water content index $\Delta h / \Delta w($ Fig. 4) shows that the suction-water content index of soils with a low clay content has less negative values. However, the lower the clay content, the higher (less negative) the suction compression index $C_{h}$ (Fig. 5). A strong linear relationship between the suction-water content index and the suction compression index has been found, expressed by the formula: $C_{h}=\left[-0.0053^{*}(\Delta h / \Delta w)\right]-0.1628$ (Fig. $6)$. This relationship reflects the correlation between changes in moisture content, suction and volume in soils. The results obtained and the distribution of data in charts 4 to 6 clearly point to a strong soil volume response to suction changes in the case of highly plastic soils with high clay content, such as Neogene clays, and a weak one in the case of glacial tills.

The comparison of soil expansivity obtained from different classification methods, based on index properties of soils and suction (Table 3), has revealed that they provide consistent expansivity ratings for glacial tills - referred to as low degree of expansivity or nonexpansive, and conflicting ratings for Neogene clays. However, the suction-based systems (USAEWES, Snethen et al., 1977; McKeen, 1992), yield the lowest ratings for clays - from high to low degree of expansion. The conclusion on the variability of the potential expansivity of Neogene clays has been additionally confirmed by numerous tests of the in situ soil suction (filter paper method) and moisture content, plotted on the McKeen (1992) classification chart (Fig. 7). 


\section{Heave of glacial tills}

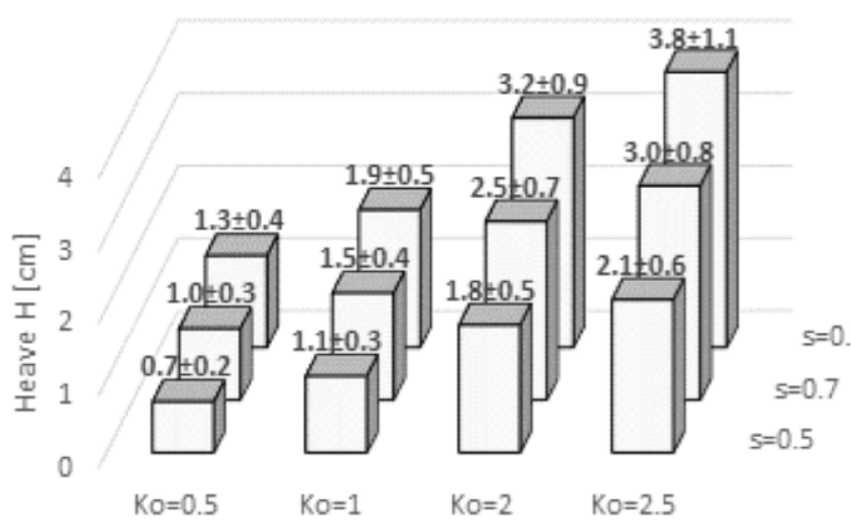

Coefficient of earth pressure at rest

\section{Heave of Neogene clays}

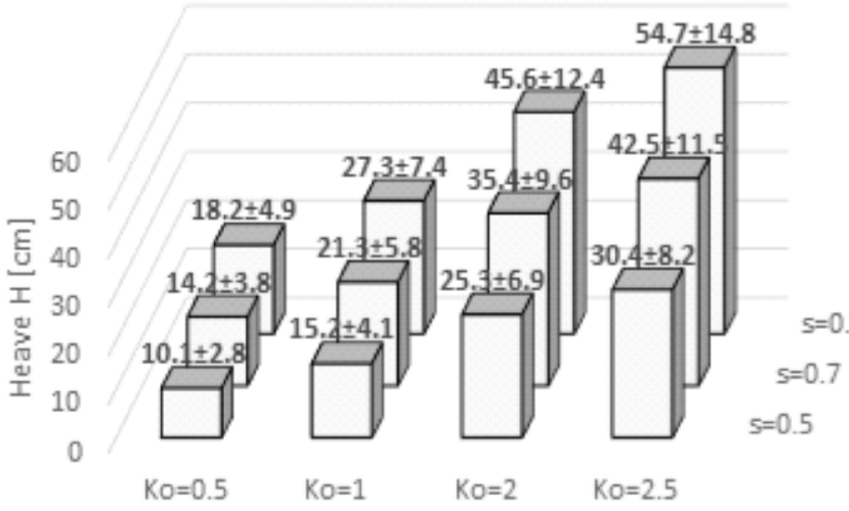

Coefficient of earth pressure at rest

\begin{tabular}{|c|c|c|c|}
\hline \multirow{2}{*}{$\begin{array}{c}\text { Coefficient for } \\
\text { load effect on } \\
\text { heave }\end{array}$} & \multicolumn{3}{|c|}{$\begin{array}{l}\text { Assumptions for heave computations } \\
\qquad \Delta H=C_{h} \Delta h \Delta t f s\end{array}$} \\
\hline & & Value & Comments \\
\hline & $C_{h}$ & $\begin{array}{l}\text { Clays: }-0.101 \pm 0.028 \\
\text { Tills: }-0.018 \pm 0.005\end{array}$ & $\begin{array}{c}\text { Measured values, } \\
\text { see Fig. } 5\end{array}$ \\
\hline & $\Delta h$ & $2 \mathrm{pF}$ & $\begin{array}{l}\text { Average of the } \\
\text { maximum suction } \\
\text { change in the field }\end{array}$ \\
\hline & $\Delta t$ & & $\begin{array}{c}\text { Typical value } \\
\text { assumed }\end{array}$ \\
\hline & & Tills: $0.6 \mathrm{~m}$ & Pisarczyk (2001) \\
\hline & $f$ & $0.67 ; 1.00 ; 1.67 ; 2.00$ & $\begin{array}{c}\text { Calculated for } \mathrm{K}_{0} \text { : } \\
0.5 ; 1 ; 2 ; 2.5\end{array}$ \\
\hline & $s$ & $0.5 ; 0.7 ; 0.9$ & $\begin{array}{l}\text { Swell pressure } \\
\text { removed: } 50 \% \text {; } \\
30 \% ; 10 \%\end{array}$ \\
\hline
\end{tabular}

Coefficient for

load effect on

heave

Fig. 8 Prediction of potential field heave of Neogene clays and glacial tills

The potential field heave of Neogene clays and glacial tills has been computed with regard to different values of load effect on heave $(s=0.5-0.9)$ and coefficient of earth pressure at rest $\left(K_{0}=0.5-2.5\right)$. For the assumed variables, the heave of Neogene clays may vary within a wide range, whereas for glacial tills, the values range between 0.7 to $3.8 \mathrm{~cm}$ (Fig. 8). In order to provide a rational estimation of expansive soil behaviour based on these findings, geotechnical engineers should take into consideration the specific site and design features.

Acknowledgements. The authors are grateful to Prof. M.K. Kumor, Prof. K. Dundulis and the anonymous Reviewer as well as Prof. T.M. Peryt for the revision and valuable comments that significantly improved the manuscript.

\section{REFERENCES}

ASTM D 2487-06. Standard Practice for Classification of Soils for Engineering Purposes (Unified Soil Classification System). American Society for Testing and Materials, Philadelphia.

ASTM D 5298-94. Standard test methods for measurement of soil potential (suction) using filter paper. American Society for Testing and Materials, Philadelphia.

Barański, M., Kaczyński, R., Borowczyk, M., Kraużlis, K., Trzciński, J., Wójcik, E., Granacki, W., Szczepański, T., Zawrzy- kraj, P., 2004. Ocena zachowania się iłów plioceńskich ze Stegien w warunkach naprężeń efektywnych (in Polish). Projekt badawczy KBN Nr 5 T12B 041 22, Archiwum NCN.

Barański, M., Wójcik, E., 2007. Ocena zdolności do zmian deformacyjnych iłów mio-plioceńskich z poligonu badawczego Stegny w Warszawie. Geologos, 11: 413-420. 
Barański, M., Wójcik, E., 2008. Estimation of ability to volume changes of Mio-Pliocene Clay from Warsaw. Geologija, 50 (Supplement): S49-S54.

Biddle, P.G., 2001. Tree root damage to buildings. Expansive clay soils and vegetative influence on shallow foundations. ASCE Geotechnical Special Publications, 116: 1-23.

Chen, F.H., 1975. Foundation on Expansive Soils. Elsevier, Amsterdam.

Fityus, S.G., Smith, D.W., Allman, M.A., 2004. Expansive soil test site near Newcastle. Journal of Geotechnical and Geoenvironmental Engineering, 130: 686-695.

Fredlund, D.G., 1995. The scope of unsaturated soil mechanics: an overview. Invited keynote address. In: Proceedings of the First International Conference on Unsaturated Soils, 3 (eds. E.E. Alonso and P. Delage): 1155-1177, A.A. Balkema, Rotterdam.

Garbulewski, K., Żakowicz S., 1995. Suction as an indicator of soil expansive potential. In: Proceedings of the First International Conference on Unsaturated Soils, 2 (eds. E.E. Alonso and P. Delage): 593-599, A.A. Balkema, Rotterdam.

Garbulewski, K., Żakowicz, S., 1993a. Ocena pecznienia drobnoziarnistych gruntów na podstawie pomiarów ssania (in Polish). Gospodarka Wodna, 3: 53-56.

Garbulewski, K., Żakowicz, S., 1993b. Potencjał ssania jako wskaźnik pęcznienia gruntów nienasyconych (in Polish). Materialy $\mathrm{X}$ Konferencji Mechaniki Gruntów i Fundamentowania, Warszawa

Gawriuczenkow, I., 2003. Effects of swelly pressure on changes in pore space morphology in Miocene clays from Warsaw: preliminary results and open questions. Geological Quarterly, 47 (2): 215-220.

Gawriuczenkow, I., 2008. Evaluation of cohesive soils of the Mazowsze region as natural geological barriers. Geologija, Vilnius, 50: $75-78$.

IS 1498, 1970. Bureau of Indian Standards. Indian Standard Classification and Identification of Soils for General Engineering Purposes. BIS, New Delhi.

Izdebska-Mucha, D., Wójcik, E., 2014. Expansivity of Neogene clays and glacial tills from Central Poland. Geological Quarterly, 58 (2): 281-290

Jeż, J., 1989. Ocena właściwości geotechnicznych podłoża gruntowego na podstawie szaty roślinnej (in Polish with English summary). Zeszyt Politechniki Poznańskiej, Rozprawy, 218.

Jeż, J., 1995. Przyrodnicze aspekty bezpiecznego budownictwa (in Polish). Wydawnictwo Politechniki Poznańskiej.

Johnson, L.P., Snethen, D.R., 1978. Prediction of potential heave of swelling soil. Geotechnical Testing Journal, GTJODJ, 1: 117-124.

Jones, L.D., Jefferson, I., 2012. Expansive soils. In: ICE Manual of Geotechnical Engineering, Volume 1, Geotechnical Engineering Principles, Problematic Soils and Site Investigation (ed. J. Burland): 413-441, London, UK, ICE Publishing.

Kaczyński, R., Grabowska-Olszewska, B., 1997. Soil mechanics of the potentially expansive clays in Poland. Applied Clay Science, 11: 337-355.

Kaczyński, R., Barański, M., Bąkowska, A., Borowczyk, M., Gawriuczenkow, I., Kiełbasiński, K., Kraużlis, K., Laskowski, K., Pietrzykowski, P., Szczepański, T., Trzciński, J., Wójcik, E., Zawrzykraj, P., 2008. Stan skonsolidowania i mikrostruktury glin zlodowacenia środkowopolskiego rejonu Warszawa-Służew na tle ich geologiczno-inżynierskich właściwości (in Polish). Projekt badawczy KBN Nr 4 T12B 062 28, Archiwum NCN.

Kaczyński, R., Bakowska, A., Kiełbasiński, K., 2010. Stressstrain behaviour of glacial till from the Ursynów suburb of Warsaw under static and dynamic loading (in Polish with English summary). Przegląd Geologiczny, 58: 873-878.

Kumor, M.K., 1990. Awarie budynków posadowionych na ekspansywnych iłach trzeciorzędowych w Bydgoszczy (in Polish). Przegląd Budowlany, 11: 471-476.
Kumor, M.K., 1994. Geotechniczna charakterystyka iłów trzeciorzędowych serii poznańskiej jako podłoża budowlanego. Iły poznańskie. Praktyczne aspekty budownictwa na gruntach ekspansywnych: 1-18, Bydgoszcz.

Kumor, M.K., 2008. Selected geotechnical problems of expansive clays in the area of Poland. Architecture Civil Engineering Environment, 1: 75-92.

McKeen, R.G., 1992. A model for predicting expansive soil behavior. Proceedings of the 7th International Conference on Expansive Soils, Dallas, 1: 1-6.

Nelson, J.D., Miller, D.J., 1992. Expansive Soils: Problems and Practice in Foundation and Pavement Engineering. John Wiley and Sons, Inc. New York.

Niedzielski, A., Młynarek, Z., van der Berg, A.P., 1988. Classification criteria of expansive soils and foundations methods used in Poland. Proceedings of International Conference on Engineering Problems of Regional Soils, Beijing: 649-653.

Pisarczyk, S., 2001. Gruntoznawstwo inżynierskie (in Polish). Wydawnictwo Naukowe PWN

Przystański, J., 1990. Posadowienie budowli na gruntach ekspansywnych. In: Instrukcje, Wytyczne, Poradniki, 296 (ed. L. Wysokiński). Ministerstwo Gospodarki Przestrzennej i Budownictwa, Instytut Techniki Budowlanej, Warszawa.

Rozporządzenie, 2012. Rozporządzenie Ministra Transportu, Budownictwa i Gospodarki Morskiej z dnia 25 kwietnia 2012 roku w sprawie ustalenia geotechnicznych warunków posadowienia obiektów budowlanych (Dz. U. z 2012 r. Nr 0, poz. 463) (in Polish).

Sawangsuriya, A., Jotisankasa, A., Vadhanabhuti, B., Lousuphap, K., 2011. Identification of potentially expansive soils causing longitudinal cracks along pavement shoulder in central Thailand. In: Unsaturated Soils: Theory and Practice 2011 (eds. A. Jotisankasa, A. Sawangsuriya, S. Soralump and W. Mairaing): 693-698. Kasetsart University, Thailand.

Seed, H.B., Woodward, R.J., Lundgren, R., 1962. Prediction of swelling potential for compacted clays. Proceedings of the American Society of Civil Engineers Journal of the Soil Mechanics and Foundations Division, 88: 53-87.

Snethen, D.R., Johnson, L.D., Patric, D.M., 1977. An evaluation of expedient methodology for identification of potentially expansive soils. Report No. FHWA-RD-77-94. United States Army Engineer Waterways Experiment Station, Vicksburg, Miss.

Szczepański, T., 2007. OCR versus YSR-a discussion of classic and today's views on preconsolidation of clayey soils (in Polish with English summary). Przegląd Geologiczny, 55: 405-410.

van der Merwe, D.H., 1964. The prediction of heave from the plasticity index and percentage clay fraction of soils. Civil Engineer in South Africa, 6: 103-106.

Wojtasik, A.T., 1994. Ekspansywność łłów w świetle badań ssania gruntu (in Polish). Ph.D. Thesis, Politechnika Poznańska, Wydział Budownictwa, Architektury i Inżynierii Środowiska. Instytut Inżynierii Lądowej.

Wojtasik, A.T., 1997. Wykorzystanie parametru ssania do obliczania potencjalnych deformacji podłoża eksopansywnego (in Polish). Materiały XI Krajowej Konferencji Mechaniaki Gruntów i Fundamentowania, Gdańsk, t. II: 321-326, Politechnika Gdańska, Gdańsk.

Yilmaz, I., 2006. Indirect estimation of the swelling percent and a new classification of soils depending on liquid limit and cation exchange capacity. Engineering Geology, 85: 295-301.

Yukselen, Y., Kaya, A., 2008. Suitability of the methylene blue test for surface area, cation exchange capacity and swell potential determination of clayey soils. Engineering Geology, 102: 38-45. 